\title{
Correlation between Cholesterol Serum Level and Xanthelasma from Januari 2014 until Desember 2018 in Dermato-Venereology Outpatient Clinic of Dr. M.Djamil Hospital Padang
}

\author{
Puridelko Kampar $^{1}$, Sri Lestari ${ }^{2}$, Qaira Anum ${ }^{2}$, Ennesta Asri ${ }^{2}$
}

\begin{abstract}
Abstrak
Xantelasma adalah penyakit kulit yang mengenai dewasa muda dan usia lebih tua. Diagnosis dapat ditegakkan hanya dengan klinis. Xantelasma dapat merupakan penanda penyakit tertentu. Hyperlipidemia dilaporkan terjadi pada sekitar $50 \%$ pasien. Belum ada data mengenai hubungan kolesterol dan xantelasma di poliklinik dermato-venereologi dari Januari 2014 sampai Desember 2018. Tujuan penelitian ini adalah menentukan hubungan kadar kolesterol dan xantelasma di klinik rawat jalan dermato-venereology Rumah Sakit Dr. M. Djamil dari Januari 2014 sampai Desember 2018. Penelitian ini adalah studi retrospektif yang dilakukan dengan menganalisis rekam medis xantelasma pasien di Poliklinik Dermato-Venereology RS Dr. M. Djamil dari Januari 2014 sampai Desember 2018. Hasil studi mendapatkan 28 pasien xantelasma dan 28 kontrol, 8 pasien (28,57\%) adalah laki-laki dan 20 pasien (71,43\%) adalah perempuan. Usia paling dominan adalah 36-45 tahun pada 15 pasien (53,57\%). Durasi onset xantelasma 50\% pasien lebih dari 2 tahun. Temuan laboratorium yang paling umum adalah hiperkolesterolemia pada 21 kasus (75\%). Dalam penelitian ini, $14,28 \%$ pasien memiliki penyakit sistemik seperti diabetes melitus dan hipertensi. Terdapat korelasi antara kadar kolesterol dan xantelasma secara statistik $(p<0,05)$. Simpulan penelitian ini adalah terdapat korelasi antara xantelasma dan kadar kolesterol yang bermakna. Xanthelasma dapat mejadi penanda hiperlipidemia.
\end{abstract}

Kata kunci: xantelasma, kadar kolesterol, hiperlipidemia

\begin{abstract}
Xanthelasma is common in middle-aged and older adults. Diagnosis can often be made on clinical based alone. Xanthelasma may be an important marker of underlying disease. Hyperlipidemia is reported occur in approximately $50 \%$ of patients. There is no data of xanthelasma in Dermato-Venereologi Outpatient clinic during from Januari in 2014 until Desember in 2018. The objective of this study was to determine the correlation between cholesterol level and xantelasma in Dermato-Venereology outpatient clinic of Dr. M. Djamil Hospital from Januari in 2014 until Desember in 2018. This retrospective study was performed by analyzed medical record of the new patient xanthelasma that visited Dermato-Venereology outpatient clinic of Dr. M. Djamil Hospital from Januari 2014 until Desember 2018. The results showed twenty eight patients xanthelasma and twenty eight controls, eight patients $(28,57 \%)$ were male and twenty patients $(71,43 \%)$ were female. Most dominant age is 36-45years, fifteen patients $(53,57 \%)$. Duration of xanthelasma in this study were $50 \%$ patients in more than two years. The most common laboratory finding which was hipercholesterolemia in twenty one cases (75\%). In this study, 14,28\% patients had assosiated with systemic diseases as diabetes mellitus and hypertension. There were correlation between cholesterol level and xanthelasma statisticaly significant with $p<0,05$. The conclusion is a correlation between xanthelasma and lipid profile an clinical classificarion of xanthelasma. Xanthelasma is a marker of hyperlipidemia that requiring a complete lipid profile to detect patients potentially to severe it.
\end{abstract}

Keywords: xanthelasma, cholesterol level, hyperlipidemia 
Affiliasi penulis: 1. Program Pendidikan Dokter Spesialis-1 Dermatologi dan Venereologi Fakultas Kedokteran Universitas Andalas Padang, 2. Bagian IImu Kesehatan Kulit dan Kelamin RSUP dr. M. Djamil Padang/Fakultas Kedokteran Universitas Andalas, Padang.

Korespondensi: Sri Lestari [srilestari_07@yahoo.com] Telp: 0751-810256/ 08126603159

\section{Introduction}

Xanthomas are plaques or nodules consisting of abnormal lipid deposition and foam cells in skin or in tendons, the most common of which is xanthelasma palpebrum, which usually appears in middle-aged females, with an incidence of $1.1 \%$, and an incidence of only $0.3 \%$ in males. ${ }^{1}$ The term "xanthelasma" is derived from the Greek word xanthos (yellow) and elasma (beat-en-metal plate). It is characterized by yellowish plaques occurring most commonly near the inner canthus of the eyelid, more often on the upper, rather than the lower lid. Lesions are symmetrically distributed, and may be singular or multiple, nodular or flat and soft, and semisolid or calcareous. ${ }^{2,3}$

Classification of xanthelasma are mention in Picture 1, (a) grade I: the lesions involve only the upper eyelids, (b) grade II: the lesions extend to the medial canthal area, (c) grade III: the lesions involve the medial side of the upper and lower eyelids, (d) grade IV: the lesions diffusely involve the medial and lateral side of the upper and lower eyelids. ${ }^{4}$

The terms dyslipidemia and hyperlipidemia are used interchangeably, but dyslipidemia is preferable as the lipids may not only be raised but may be present in altered proportions. Xanthelasma is a marker of dyslipidemia, requiring a complete lipid profile to detect patients potentially at increased risk of cardiovascular disease. However, only about half of the patients with xanthelasma are hyperlipidemia. The most frequent Fredrickson hyperlipidemic phenotype in hyperlipidemic patients with xanthelasma is type Ila. Lesss frequently found are types IIb,III, and IV. The prevalence of type Ila phenotype with xanthelasma is two to three times greater than the prevalence of this phenotype in a matched gruop of patient with dyslipoproteinemia but without xanthelasmas. ${ }^{5}$ Xanthelasmas can be found in patients with elevated LDL cholesterol levels, but most often occur in patients with relatively normal lipid levels. ${ }^{6,7}$

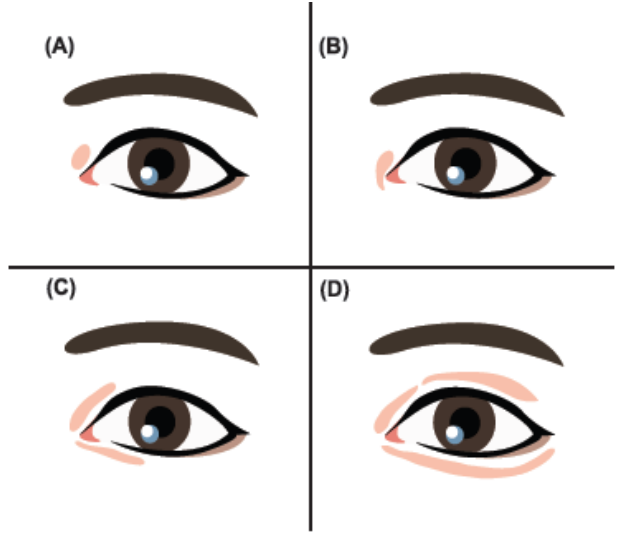

Picture 1. Classification of xanthelasma ${ }^{4}$

Lipids are transported in the blood as small spherical particles, the lipoproteins. The function of the protein coating is to confer water solubility to the lipids and to provide cellular receptors and enzymes essential for lipid metabolism. Proteins in the coating with special functions are called apoproteins. The lipoproteins are derived from 2 sources-diet (exogenous) and liver (endogenous). They consists mainly of cholesterol, phospholipid and triglyceride. High-density lipoproteins (HDL) are composed mostly of phospolipids and esterified cholesterol. They are beneficial because they clean up molecules released into the circulation during the transport of triglyceriderich lipoprotein particles. Low-density lipoproteins (LDL) are consist mainly of cholesterol. LDL is the major atherogenic lipoprotein and raised serum levels are associatede with coronary heart diseases. ${ }^{7}$

Hyperlipidemias may be primary or secondary. Primary hyperlipidemias are due to severe genetic defects in lipid metabolism or less severe defects plus aggravating factors. Secondary hyperlipidemias are resultr of other diseases and drugs. The hyperlipidemias are associated with characteristics skin lessions. The main lipid that is stored in both hyperlipidemic and normolipidemic xanthelasmas is cholesterol. Some investigators have observed that xanthelasmas in normolipidemic patients do not differ ultrastructurally from hyperlipidemic xanthelasmas or other types of hypercholesterolemic xanthomas. ${ }^{6,7}$ However, xanthelasmas do not develop in most patients with hypercholesterolemia and these lesions can also develop in normolipidemic patients. ${ }^{5}$ 
Histologically, xanthelasma resemble other xanthomas, that are associated with hypercholesterolemia, they are composed af foamy histiocytes with occasional Touton giant cells. They differ from other types of xanthomas by the superficial location of the foam cells and the nearly complete absence of fibrosis. Ultrastructurally, xanthelasmas resemble other types of hypecholesterolemic xanthomas. The eyelids are exposed to constant movement and friction, and this might be the reason why xanthelasmas develop in these areas. There might also be an intrinsic sensitivity in this patients to this proposed capillary leakage. ${ }^{5}$

A benign condition which never limits function, xanthelasma palpebrarum is cosmetically disturbing, therefore, patients consult dermatologists, ophthalmologists, or surgeons for lesion removal. Several methods are used to treat xanthelasma palpebrarum and these include simple surgical excision, cryotherapy, chemical peeling with trichloroacetic acid (TCA), radiofrequency (RF), and laser treatment. Each modality has its own advantages and disadvantages. ${ }^{7}$

For dermatologists seeking to evaluate the causes of xanthelasmas, the standard approach is to order a serum or plasma lipid profile, performed after the patient fasts overnight. These studies permit consideration of secondary causes of lipid abnormalities, particularly if the patient has elevations of LDL cholesterol (>150 mg/ dL) or triglycerides (>150 $\mathrm{mg} / \mathrm{dL})$, or decreased levels of HDL cholesterol $(<55$ $\mathrm{mg} / \mathrm{dL}){ }^{1}$ The aim of this study is to know the correlation of lipid profile and xantelasma clinical classification in Dermato-Venereology outpatient clinic from Januari 2014 until July 2018.

\section{Methods}

Retrospective study was performed by analyzed medical record of the new patient that visited Dermato-Venereology Outpatientclinic of Dr. M. Djamil
Hospital from Januari 2014 until Desember 2018. Variables studied were age, sex and lipid profile dan clinical classification of the patients.

\section{RESULTS}

Twenty eight patients were studied during the periode January 2014 until Desember 2018. Twenty patient $(66,67 \%)$ were females and $8(33,33 \%)$ were males with $2: 1$ ratio. The patient $>26-\leq 35 y$ years old were $5,55 \%$ and $>36-\leq 45$ years old were $44,44 \%$. The patient had duration xanthelasma less than one year were 3 patients $(16,67 \%)$ as seen in Table 1.

Table 1. Demographic characteristic of xanthelasma

\begin{tabular}{lcc}
\hline \multicolumn{1}{c}{ Characters } & Number & $\%$ \\
\hline Sex & & \\
\multicolumn{1}{c}{ Male } & 8 & $28,57 \%$ \\
Female & 20 & $71,43 \%$ \\
Age & & \\
\multicolumn{1}{c}{$>18-\leq 25$} & 0 & $0 \%$ \\
$>26-\leq 35$ & 3 & $10,71 \%$ \\
$>36-\leq 45$ & 15 & $53,57 \%$ \\
$>46-\leq 55$ & 5 & $17,86 \%$ \\
$>56-\leq 65$ & 2 & $7,14 \%$ \\
$\quad>65$ & 3 & $10,71 \%$ \\
Duration & & \\
Less than 1 year & 8 & $28,57 \%$ \\
Between 1 and 2 years & 6 & $21,43 \%$ \\
More than 2 years & 14 & $50,00 \%$ \\
\hline
\end{tabular}

Table 2 show the lipid abnormalities of xanthelasma patients. Increase of total cholesterol and decrease of HDL were the most common lipid abnormalities of xanthelasma (75\% and 64\%), followed by elevated of trigliseride $(64,28 \%)$ and increase of LDL cholesterol level (35,71\%) and associated with systemic diseases were 4 patients. Clinical classification of xantelasma grade I, 20 patient $(71,43 \%)$, grade II $(14,28 \%)$, grade III $(10,71 \%)$, grade IV $(3,57 \%)$ as shown in Table 3. 
Table 2. Distribution of plasma lipid profile of xanthelasma

\begin{tabular}{lccc}
\hline \multicolumn{1}{c}{$\begin{array}{c}\text { Lipid } \\
\text { Abnormalities }\end{array}$} & Range & Number & $\%$ \\
\hline Total cholesterol & $>200$ & 21 & $75,00 \%$ \\
& $\mathrm{mg} / \mathrm{dl}$ & & \\
LDL cholesterol & $>150$ & 10 & $35,71 \%$ \\
& $\mathrm{mg} / \mathrm{dl}$ & & \\
HDL cholesterol & $<55 \mathrm{mg} / \mathrm{dl}$ & 18 & $64,28 \%$ \\
Trigliserida & $>150 \mathrm{mg} / \mathrm{dl}$ & 13 & $46,23 \%$ \\
& & & \\
Associated & - & 4 & $14,28 \%$ \\
systemic & & & \\
disorders & & & \\
\hline
\end{tabular}

Table 3. Distribution of clinical classification of xantelasma

\begin{tabular}{lcc}
\hline $\begin{array}{c}\text { Clinical } \\
\text { classification }\end{array}$ & Number & $\%$ \\
\hline Grade I & 20 & $71,43 \%$ \\
Grade II & 4 & $14,28 \%$ \\
Grade III & 3 & $10,71 \%$ \\
Grade IV & 1 & $3,57 \%$ \\
\hline
\end{tabular}

Table 4. Correlation between cholesterol level and xantelasma

\begin{tabular}{lcc}
\hline & Cholesterol level & P \\
\hline Xanthelasma & $224,61 \pm 29,77$ & $0,000^{*}$ \\
Control & $169,39 \pm 35,83$ & \\
\hline
\end{tabular}

Table 4 show there was the correlation between lipid profile and clinical classification of xantelasma, with $p<0,05$

\section{DISCUSSION}

According to the fifth years report during Januari 2014 until Desember 2018, has been found 28 cases xanthelasma palpebrarum and more common in women than man. This study consistent with Özdöl et al (Turkey,2008) that was reported from 200 xanthelasma patients with the demographic and clinical characteristics data of the two groups have mean age $49 \pm 11$ years and most patient were women as 66 patients (66\%). ${ }^{6}$ As well as study by Bergman R (Israel,1994) who said that xanthelasma are more common in women and tend to increase in prevalence with age. ${ }^{5}$

In this study, the most affected age groups was $>36-<45$ years old $(53,57 \%)$, which was similar to the data published in many literature that xanthelasma can be encountered at middle-aged and older adults. ${ }^{3}$ In this study, most of the patients $(50 \%)$ who came to dermatology and venereology out patient with less than a 12-month duration. This may be related to the fact that the majority of xanthelasma palpebrarum cases are reported in females, who are more conscious about cosmetic issues. ${ }^{8,9}$

It is essential to obtain blood samples after a fasting period of 12-16 hours and to avoid food extremely rich in carbohydrates and fats. In this study, serum levels of $\mathrm{HDL}(<50 \mathrm{mg} / \mathrm{dl})$ and cholesterol (>200 mg/dl) were found in $75 \%$ and $64 \%$ patients. This is probably due to pattern of consumption most people in Padang that contain lots of cholesterol. Jain observed significantly high mean serum values for triglycerides and cholesterol in xanthelasma palpebrarum. ${ }^{10}$ Rubinstein et al (Texas, 2014) also observed significantly high mean serum values for triglycerides and cholesterol in xanthelasma palpebrarum. ${ }^{9}$ Meanwhile, Sharma et al (India, 2013) did not find any significant difference in mean trigliserida level between the patient and normal groups. ${ }^{11}$

In this study, there are four patients who have systemic diseases disorders that is diabetes and hipertension. This is accordance with study by Pitambe and Schulz (South Africa, 2005) who said that dyslipidemia in diabetes mellitus usually occur in young insulin-resistent diabetics. ${ }^{7}$ Insulin is necessary for the normal clearing action of lipoprotein lipase on triglyceridemia results in eruptive xanthomas that clear on treatment. Jain et al (India,1998) was reported xanthelasma palpebrarum assoaciated systemic disease in $42 \%$ of cases. ${ }^{10}$ The primary cause can be inherited or appear in systemic diseases where high lipid level occur, for example, in diabetes mellitus, hypothyroidsm, obesity, liver disturbance, nephrotic syndrome, biliary tract obstruction. The early diagnosis of the underlying disease can significantly affect future health. ${ }^{11,12}$ 


\section{CONCLUSION}

There was correlation between xanthelasma and lipid profile an clinical classificarion of xanthelasma. Xanthelasma is a marker of hyperlipidemia that requiring a complete lipid profile to detect patients potentially to severe it.

\section{ACKNOWLEDGEMENT}

This study was not sponsored and there are no conflicts of interest

\section{REFERENCES}

1. Schaefer EJ, Santos RD. Xanthomatoses and lipoprotein disorders. In: Goldsmith LA, Katz SI, Gilchrest BA, Paller AS, Leffell DJ, Wolff K, editors. Fitzpatrick's dermatology in general medicine. 8th Ed. New York: McGraw-Hill; 2012: 1600-1612.

2. James W, Berger TG, Elston DM. Xantomatoses in Andrew's disease of the skin clinical dermatology.10th Ed. Philadelphia: Saundres and Elsevier, 2011:vol12;p.531-32.

3. Gangopadhyay DN, Dey SK, Chandra M, Chaudhary S. Serum lipid profile in xanthelasma. Indian J Dermatol. India; 1998;43:53-6.

4. Wang H, Shi Y, Guan H, Liu C, Zhang W, Zhang Y, et al. Treatment of xanthelasma palpebrarum with intralesional pingyangmycin. Dermatol surg. 2016;42:368-76.
5. Bergman R. The pathogenesis and clinical significance of xanthelasma palpebrarum. J Am Acad Dermatol. Israel.1994;30:236-42.

6. Özdöl S, Sahin S, Tokgözoglu L, Xanthelasma palpebrarum and its relation to atherosclerotic risk factors and lipoprotein. International Journal of Dermatology, Turkey. 2008:47:785-9.

7. Pitambe HV, Schulz EJ. Life-threatening dermatosies due to metabolic and endocrine disorders. Clinics in Dermatology South Africa. 2005:23:258-66.

8. Nair PA, Singhal R, Xanthelasm palpebrarum. Clin Cosmet Investig Dermatol, India. 2017;11:1-5.

9. Rubinstein TJ, Mehta MP, Schoenfield L, Perry JD. Orbital xanthogranuloma in an adult patient with xanthelasma palpebrarum and hyper cholesterolemia. Ophthal Plast Reconstr Surg,Texas. 2014;30:6-8.

10. Jain A, Goyal P, Nigam PK, Gurbaksh H, Sharma RC. Xanthelasma palpebrarum: Clinical and biochemical profile in a tertiary care hospital of Delhi. Indian Journal of Clinical Biochemistry. 2007;22(2):151-3.

11. Sharma P, Patgiri D, Sharma G, Pathak MS. Serum lipid profile in xanthelasma palpebrum. Indian J Basic Appl Med Res. India; 2013;7:732-7.

12. Gangopadhyay DN, Dey SK, Chandra M, Pal D, Chaudhary S. Serum lipid profile in xanthelasma. Indian J Dermatol, India. 1998;43:53-6. 